\title{
MEASURING FIRM PERCEPTION TO ADAPTATION OF INDUSTRY 4.0: THE CASE OF TURKEY
}

Ebru AŞAR ${ }^{1}$, Filiz BÜLBÜL² ${ }^{2}$ Mansur AKBULUT ${ }^{3}$, Pınar BAYARSLAN ${ }^{4}$, Tunahan KERMEN ${ }^{5}$, Derya FINDIK ${ }^{6}$

\section{ABSTRACT}

Purpose: This study aims at examining the perceptions of various layers within a firm toward integrating Industry 4.0 applications in production.

Methodology: We follow a case study approach to obtain detailed information about the selected firm. We focus on machinery, food, and automotive spare parts sectors having a strategic role in digital transformation. In total, 12 interviews with blue-collar workers, engineers, and managers are conducted in five different companies.

Findings: The results of the study are twofold. As for the senior management layer and engineers, the adaptation of Industry 4.0 applications to the firm will increase the firm efficiency. As far as its effect on employment is considered, it has been determined that the concept is not fully understood, especially by blue-collar workers, and it is not known how it will contribute to production. Production line workers, therefore, think that they will experience the threat of losing their jobs with the implementation of Industry 4.0 applications.

Originality: Despite its importance, the number of studies dealing with the difficulties, benefits, opportunities, and threats of adopting Industry 4.0 especially for developing countries is still few. This study, therefore, closes this gap by conducting a comprehensive study with various layers of the firm.

Keywords: Industry 4.0, Supply Chain Management, Case Study.

JEL Codes: L2, L6, M2.

\section{ENDÜSTRI 4.0'IN ADAPTASYONUNA YÖNELIK FIRMA ALGISININ ÖLÇÜLMESI: TÜRKIYE ÖRNEĞi}

ÖZET

Amaç: Bu çalışma, bir firma içindeki çeşitli birimlerin üretimde Endüstri 4.0 uygulamalarının kullanılmasına yönelik algılarını incelemeyi amaçlamaktadır.

Yöntem: Firmadaki çeşitli birimlerin algılarını analiz etmek için vaka çalışması yaklaşımı kullanılmıştır. Dijital dönüşümde stratejik rolü olan makine, gıda ve otomotiv yedek parçaları sektörlerine odaklanılmıştır. Toplamda beş farklı firmada mavi yakalı işçi, mühendis ve yönetici ile 12 görüşme yapıımıştır.

Bulgular: Çalışmanın sonuçları iki yönlüdür. Üst yönetim kademesi ve mühendislere göre, Endüstri 4.0 uygulamalarının firmaya uyarlanması, üretim sürecini iyileştirecek ve verimliliği artıracaktır. İstihdam üzerindeki etkisi düşünüldüğünde ise, kavramın özellikle mavi yakalı çalışanlar tarafından tam olarak anlaşılmadığı ve üretime nasıl bir katkı sağlayacağının bilinmediği tespit edilmiştir. Bu nedenle üretim hattı çalışanları, Endüstri 4.0 uygulamalarının hayata geçirilmesiyle işlerini kaybetme tehdidini yaşayacaklarını düşünmektedirler.

Özgünlük: Endüstri 4.0'ın özellikle gelişmekte olan ülkelerde benimsenmesi önündeki zorlukları, sağladığı faydaları, sunduğu fırsatları ve yarattığı tehditleri ele alan çalışmaların sayısı hala azdır. Bu çalışmada, firmanın çeşitli katmanlarının algıları kapsamlı bir şekilde analiz edildiği için yazına katkı sağlanmıştır.

Anahtar Kelimeler: Endüstri 4.0, Tedarik Zinciri Yönetimi, Vaka Çalışması.

JEL Kodları: L2, L6, M2.

\footnotetext{
1 Postgraduate Student, Ankara Yıldırım Beyazıt University, Faculty of Business, Department of Management Information Systems, Ankara, Turkey, asrebru@gmail.com, ORCID:0000-0001-9182-8732.

2 Postgraduate Student, Ankara Yıldırım Beyazıt University, Faculty of Business, Department of Management Information Systems, filizbulbul91@gmail.com, ORCID: 0000-0001-9477-7811.

${ }^{3}$ Postgraduate Student, Ankara Ankara Yıldırım Beyazıt University, Faculty of Business, Department of Management Information Systems, m.mansurakbulut@gmail.com, ORCID: 0000-0002-7677-8586.

4 Postgraduate Student, Ankara Yıldırım Beyazıt University, Faculty of Business, Department of Management Information Systems, pinarbayarslan@gmail.com, ORCID: 0000-0003-1418-6021.

5 Postgraduate Student, Ankara Yıldırım Beyazıt University, Faculty of Business, Department of Management Information Systems, kermentunahan@gmail.com, ORCID: 0000-0001-7184-8840.

${ }^{6}$ Doç. Dr., Ankara Yıldırım Beyazıt University, Faculty of Business, Department of Management Information Systems, Ankara, Turkey, dfindik@ybu.edu.tr, ORCID: 0000-0002-3002-4391 (Sorumlu Yazar-Corresponding Author).
} 


\section{INTRODUCTION}

Today, the industrial powers of early-developed countries have been shaped by the fourth phase of industrialization, Industry 4.0, which is based on a high level of automation (Stock and Seliger, 2016). The new process brings several changes in both production processes and customer relationships. It includes key elements as Cyber-Physical Systems, the Internet of Things, the Internet of service, and the Smart Factory (Brettel et al., 2017). Besides, Industry 4.0 allows physical objects to communicate with each other and with humans by monitoring physical operations with physical systems in modular smart factories, thereby resulting in decentralized business decisions.

In today's competitive environment, firms implement Industry 4.0 applications to protect their strategic resources (He and Jin, 2016). Using the information obtained from different sources, Industry 4.0 succeeds to create a link between man and machine in the context of cyber-physical systems (Monostori, 2015). Implementation of such a network in the production and operational environment generates several effects on the entire supply chain and overall productivity. It provides transparency between various stakeholders including customers and suppliers. Additionally, with the use of Industry 4.0, the entire supply chain management structure is automated which in turn shortens lead-time (Tjahjono et al., 2017). All these changes play crucial roles in the firm's productivity. For this purpose, we aim at examining the perceptions of various layers within a firm to understand the opportunities and potential threats of integrating Industry 4.0 applications into the production system. By doing this, we try to understand whether it will increase productivity or not. To have a comprehensive perspective, we focus on certain sectors such as the machinery, food, and automotive spare parts sectors playing an important role in the digital transformation of production. As interviews are conducted with firm representatives from different sectors, comparative results have been obtained for Industry 4.0 applications, revealing the current and future situations.

This study contributes to the related literature in at least three ways. In addition to other country cases such as Brazil (Torterella and Fetterman, 2018) and Italy (Zheng et al., 2019), this study represents a comprehensive example including different layers of the firm. By following the framework of Orlikowski (1993), we analyze whether top management, engineers, and production workers have similar perceptions toward Industry 4.0 applications. To formulate any policy targeting the successful implementation of Industry 4.0, it is necessary to learn feedback from production workers as well as professionals and top management. Moreover, the number of studies dealing with difficulties and benefits that firms in developing countries face is still few. It is clear that developing economies and transition countries face various challenges in the pre-implementation process (Haaker et al. 2021). This study fills this gap by focusing on certain sectors in Turkey. Finally, yet importantly, in the light of the results of this study, a list of necessary policy implications at various levels will be possible.

This paper is organized as follows: Section 2 briefly discusses the literature. The data and methodology are explained in Section 3. Section 4 introduces interview results. Section 5 discusses the results' implications and concluding remarks.

\section{LITERATURE REVIEW}

Industry 4.0 refers to the automation and data exchange activities in production technologies. It was first announced in 2011 to increase German competitiveness in the manufacturing industry (Kagermann, et al., 2013). Machines, objects, and systems communicating with each other provide benefits such as analyzing and understanding production issues, then solving them with minimal human involvement, and automating production lines (Tjahjono, et al., 2017). Industry 4.0 will significantly affect people's working environments. When advanced technologies are applied in businesses, processes such as purchasing, production, the processes of sales and maintenance will change which in turn increases business value (Prifti et al., 2020).

The important components of Industry 4.0 include Cyber-Physical Systems, Internet of Things (loT), Internet Services (IoS), Smart factory, Big Data Analytics, Simulation, Autonomous Robots, Cloud Computing, Additive Manufacturing, and Augmented Reality (Sniderman et al., 2016).

A system that provides communication and coordination between the physical world and the cyber world is called as Cyber-Physical Systems (CPS). It covers compute and storage capacity, mechanics, and electronics (Baheti and Gill, 2011). Accordingly, the Internet is a communication medium (Schmidt et al., 2015). The main role of the CPS is to respond to the changing requirements of production, thereby improving the efficacy and efficiency of the firm's operations (Brettel et al., 2017). Industry 4.0 is characterized by an unprecedented connection between the Internet and the CPS, which provides a completely new level of control, oversight, transparency, and efficiency in the production process (Parvin et al., 2013). 
CPS uses two parallel networks to control the communication links between the physical network of interconnected components of the infrastructure and a cyber network (Parvin et al., 2013). It integrates these networks using multiple sensors, actuators, control processing units, and communication devices (Hofmann and Rüsch, 2017).

Another component of Industry 4.0 includes IoT. It refers to a network wherein the CPS cooperates with other components via unique addressing schemes (Hermann et al., 2015). The internet of things (IoT) is the movement to attach physical things to the internet and each other through wireless technology. This system permits objects and machines consisting of cell phones and sensors to "communicate" with each other as well as human beings (Holdowsky et al., 2015). In the first decade of the 21st century, the "internet of things" has become popular and is thought of as a technology that allows industries to get through from Industry 3.0 to Industry 4.0 by adding information to the products and processes in the supply chain (Hermann et al., 2015).

Additionally, IOT is based on low-cost sensor technologies such as radio frequency identification (RFID) devices and includes a wide range of devices, such as sensors, actuators, robots, milling machines, 3D printers, and assembly line components, chemical mixing tanks, motors, planes, trains, and automobiles (Thames and Schaefer, 2016). The loT provides enhanced connectivity of devices and products through machine-to-machine (M2M) or human-machine (H2M) communication (Holler et al., 2014). Each device connected to the Internet expects to have several smart services called Internet Services (IoS) (Monnier, 2013). Thus, services are made easily accessible through web technologies, with the help of these technologies (Wahlster et al., 2014).

So far, CPS, IoT, and loS have been introduced as key components of Industry 4.0. The CPS has a structure called "Smart factory" which is a decentralized production system based on the connection between loT and loS. People, machines, and resources communicate with each other as if they were on a social network (Kagermann et al., 2013). Thus, products, machinery, transportation systems, and close links and communication between people are expected to change the current production model.

Each firms' supply chain system depends on operational needs. Organizations are based on external inputs where the supply chain is made up of materials, parts, and other physical materials or data, information, and expertise. The use of Industry 4.0 helps organizations integrate planning and inventory processes and other capabilities (Mussomeli et al., 2016). Supplier factors are related to goods flow and supplier information. Each asset in the supply chain must be synchronized with changes in the business process of the manufacturer. Thus, technological networks are set up among various partners through Industry 4.0 (Sanders et al., 2016). These networks help to share material resources such as intangible assets such as research and information, data, information and machinery, equipment, and human experts (Tepeš et al., 2015). This alone will generate some difficulties and opportunities in the supply chain, many of which can be experienced by taking advantage of Industry 4.0 solutions.

3-D printing is another type of Industry 4.0 component that will be widely used in plant operations soon. It reflects the physical work in a virtual model by using real-time data. The use of this technology help firms reduces manufacturing costs, thereby increasing quality (Brettel et al., 2017). As observed in the case of Siemens and a German machine-tool vendor, the virtual machine is developed that can simulate the processing of parts using data from the physical machine. This reduces the installation time of the actual machining process to 80 percent.

Autonomous Robots are robotic systems with a certain level of intelligence conducting automatic operation functions. The size can vary considerably in terms of functionality, mobility, skill, intelligence, and cost (Fitzgerald and Quasney, 2017). Autonomous robots are expected to grow largely in supply chain operations. The continuous growth of autonomous robots allows those who perform these tasks to move to a strategic, less dangerous, and higher-value job. Autonomous robots expand in their use of more consistent quality and productivity levels, as people can perform tasks that they cannot or will not do or want to do (Brewster, 2016). As autonomous robots grow in size, the supply chain operations will be smoother. Many firms that use autonomous robots take advantage of a variety of robots to validate their expected productivity gains by using them in the supply chain. As innovative firms grow and expand, autonomous robots become a standard for optimizing production operations economically and efficiently. As a result of the widespread deployment of the robotics sector from the agricultural sector to the retail sector to the storage systems, cost reduction and productivity increase are expected in the supply chain (Fitzgerald and Quasney, 2017).

Additive manufacturing (AM) has been used for years to create prototypes in large quantities. Shortly, with the emergence of Industry 4.0, a broader understanding of AM's potential for value in product production, supply chain structure, and new business models have emerged (Cotteleer and Joyce, 2014). 
Progress in technology has made a wider range of materials and increased operational competencies a more viable option for firms to consider (Cotteleer and Joyce, 2014).

Augmented-Reality-based systems are composed of services varying from selecting parts in a warehouse to sending repair instructions via mobile devices. Firms will rely on that technology to improve decision-making, work procedures for employees, and provide real-time information (Rüßmann et al., 2015). For example, employees will obtain information about the parts of the machine that need to be repaired using devices such as increased reality glasses. (Rüßmann et al., 2015).

Although it is used by manufacturers, the need for cloud-based software will increase even more due to the operations that require data sharing between firms and external stakeholders. Under the Industry 4.0 regime, the possibility of analyzing large-scale data is useful to make predictions for production activities and is an important issue for industrial technology development.

Considering the empirical literature on the adoption of Industry 4.0 on firm performance, studies are heavily based on developed countries. To illustrate, Chiarini et al. (2020) revealed that the practice of Industry 4.0 in Italian manufacturing results in performance increases in production processes. For some industries, the adoption of Industry 4.0 may generate a direct effect on performance, it affects the outcome through supply chain processes for some others. Delic and Eyers (2020) have found that the adoption of Additive Manufacturing in the automotive sector positively affects supply chain flexibility which in turn improves firm performance. Another example is related to cloud ERP systems. Accordingly, the integration of cloud ERP positively affects all the indicators of sustainable performance indicators (Gupta et al., 2020). Some strands of literature deal with the adoption of big data and its performance effects. Mikalef et al. (2020) found that the use of big data analytics for firm operations increases the competitive advantage of the firm because it provides such advantages as higher operational capability.

\section{DATA and METHODOLOGY}

This study started with a desk-based study using various literature sources as primary data sources such as articles, scientific research, firm reports, and business journal. To find out relevant papers, we chose Industry 4.0, Supply Chain, and Supply Chain Management as keywords to access scientific papers through the Web of Science. After going deeper into the topic, we have extended the keywords by adding two important terms such as Internet of Things (IOT) and Cyber-Physical Systems. The search gave dozens of results, which signals Fourth Industrial Revolution is an emerging term for the literature. Thus, the papers were attentively reviewed to eliminate unrelated ones. The relevant papers were selected among the studies that are directly related to the topic of this study. Finally, 33 scientific papers were left on hand.

Since the purpose of this paper is to show the real interaction between Industry 4.0 and Supply Chain Management, we followed the interview technique to better understand the perceptions of different layers of the selected firm. Interview questions were constructed based on the papers we reviewed.

The interviews were held with representatives in various positions such as managers, engineers, and production line workers from the machinery, food, and automotive spare parts sectors. These sectors were chosen due to their large impact on the country's economy. Moreover, considering the digital transformation of the industry, these sectors are in the first place. (11 th Development Plan, 2019-2023). In total, 12 interviews were conducted, and each interview took 40 minutes on average.

To understand the transition phase to Industry 4.0 and its impact on supply chain management, this study constitutes a comprehensive example. Based on our interviews, many questions arise concerning the fourth industrial revolution, technology use, and supply chain management. The interviews include yesno and open-ended questions such that "Have you heard the Industry 4.0 term before?" "How much did the Fourth Industrial Revolution affect supply chain management?" "Are your existing supply chain structures compatible with Industry 4.0 solutions?" "How will supply chains be in the future with Industry 4.0 implementations?' The interview questions were designed according to received answers which can change the next questions for interviewees.

To illustrate, if the term Industry 4.0 is not known, the interview goes on with the questions of technology awareness and use. Since the interviews were held in firms in different sectors, the comparative results of Industry 4.0 applications which show the current and future situations were obtained.

Since the term Industry 4.0 is a new concept for Turkey, there are some uncertainties about the definition and domain of this term for the firms. In many cases, firms are reluctant to share knowledge about their future production activities. Despite these difficulties, we interviewed more than one firm, thereby obtaining comparable experiences. 


\section{RESULTS}

Table 1 demonstrates the detailed information about the selected firms in this study. Also, it shows the organizational changes with the implementation of Industry 4.0 for each firm. To evaluate the results of the interviews, we followed the framework of Orlikowski (1993). For the firms operating in the automotive industry, they are labeled as AU1, AU2, and AU3, respectively. Remained sectors are construction (MS) and food (FS). Additionally, firms are classified in terms of their implementation level such as implemented, almost fully implemented, and not implemented. Table 2 shows the comparison between AU1, MS, and FS.

\section{AU1}

AU1 is the leading firm in the automotive supplier industry in Turkey. The technology in the firm plays a significant role in its current position in the sector. During the interview, we observed that they have an advanced workstation and an interest in new technologies in the automotive industry. The interviews were held with three positions as manager, engineer, and assembly line worker. The answers from the manager and the engineer are similar and they both are knowledgeable about the research topic. Besides, they have a high level of interest in technological developments. The production line worker, on the other hand, does not have information about Industry 4.0.

The firm has been invested in technology since it was founded, so Industry 4.0 concept does not refer to a substantial change. The manager gave an example to show how well the firm is compatible with the Industry 4.0 concept. He said that an Indian group came to the firm to tell Industry 4.0 activities last month and they stayed a week. When the group left, there was nothing new for AU1. The manager added that they were already knowledgeable about Industry 4.0 concept. The firm is eager to take full advantage of new technologies such as Industry 4.0. The interviewees said that they were already too digital when the term Industry 4.0 appeared, and they added that they can take further steps in the field of Industry 4.0.

When we check the requirements of the Industry 4.0 concept, it can be observed that the existing systems of the firm are compatible with the system requirements of Industry 4.0. To illustrate, AU1 has various software systems to provide an integration between business units and customers and to control the production process with the minimum involvement of the human factor. The answers to the questions about the future of Industry 4.0, therefore, were positive. According to their perspectives, if firms adopt the Industry 4.0 concept, there will be momentous changes in manufacturing soon. Besides, the interviewees believe that many jobs will disappear, but new ones will emerge shortly after the diffusion of Industry 4.0. Even the people at the bottom of the pyramid will be more skillful because this concept will push people to improve themselves.

Regarding the supply chain management questions, the firm uses Industry 4.0 applications a hundred percent in the supply chain process. The number of blue-collar workers in the supply chain will not change significantly in AU1 but the interviewees do not have the same opinion for the firms which rely on manual processes. If these firms want to be more digital and smarter, they will adopt Industry 4.0, thereby laying off several workers.

The impression during the interview indicates that the decision-makers are aware of Industry 4.0 and the firm makes continuous investments in technological development. There is one problem regarding workers in the production line. They are important actors of the production system, but they do not know the concepts.

\section{AU2}

AU2 is one of the new firms in the automotive supplier industry in Turkey. Although the firm has a 10year history, the technology level is quite satisfactory. Since the founders of the firm are ex-employees of a Japanese brand, the influences of Japanese culture such as lifelong employment and inter-personal trust can be observed. The interviews were held with three positions as manager, engineer, and assembly-line worker. The manager and engineer preferred to answer the questions together due to the unexpected workload at the interview time. During the interview, it is observed that the manager and the engineer are knowledgeable about Industry 4.0, but the assembly line worker is not aware of the term similar to AU1. Thus, the assessment of the firm regarding the implementation of Industry 4.0 is based on the perceptions of two layers.

As the firm was founded in the digital age, the use of advanced technologies can be observed in every single process. Industry 4.0 is interpreted as "the future" by the manager and the engineer. The firm believes that if a well-designed investment is made in technology, the position of the firm gets stronger. AU2 holds several meetings for digitalization which are generally organized by the R\&D department. The outcome of the meetings supports that adopting the Industry 4.0 concept increases the efficiency of 
business activities. Also, the firm attends domestic and foreign trade fairs for the same purpose. Thanks to the fairs and the meetings, the firm becomes more innovative day by day. For instance, new production processes are added to the existing system and all processes are monitored at different points. Besides, the firm uses software systems integrated with suppliers, customers, and internal departments. As far as the questions about the future are considered, the manager and the engineer believe that the production processes will completely change and if employees cannot keep pace with this change, most of them will be eliminated. Additionally, some jobs will disappear, and the number of blue-collar employees will decrease compared to white-collar ones. The manager indicated that Industry 4.0 will upgrade workers and there will not be a significant change in the number of workers in the supply chain because the business volume gradually increases. In the current situation, the firm uses Industry 4.0 sixty percent in the supply chain. The full implementation of the Industry 4.0 concept to the supply chain will reduce the margin of error in production and thus better-quality products will be produced.

The engineer, on the other hand, has a more pessimistic attitude towards the effects of Industry 4.0 on employees. Accordingly, Industry 4.0 will have a deskilling impact on workers. The recruitment process will be conducted based on the requirements of the new business systems.

\section{AU3}

Unlike AU1 and AU2, AU3 is a member of an international group. Since the firm produces automotive spare parts, the technological advancement of the firm is at a certain level. However, the other production units of the same international group in different countries use more advanced technology in the production. In AU3, the interviews were held with a manager, an engineer, and a worker from the product line. The answers were not different in terms of the awareness of Industry 4.0 when compared to the other two firms but there are differences concerning the implementation of Industry 4.0.

According to received answers from the manager and the engineer, they are aware of the Industry 4.0 concept but there has not been any specific effort to implement this concept until now. The reason might be that the firm is satisfied with its existing systems or the firm believes that the implementation will be costly. When we compare the responses of the engineer and the manager, the engineer was more excited and interested in the Industry 4.0 concept. The manager, on the other hand, did not seem relevant to the issue of the implementation of Industry 4.0. According to the engineer, if the firm goes on with the current systems, some troubles such as an increasing churn rate and inability to sustain competitive power can appear in the rapidly changing market. AU3 improves itself but not specifically in the field of Industry 4.0. The engineer believes that the Industry 4.0 concept will bring brand-new technological developments and provide a competitive advantage.

MS

The firm has been serving the whole world with business and construction machines since 1972. It has been very successful with its wide product range and quality service. It has been in operation for more than 40 years, specialized in business machines, and provides solutions for customers' commercial needs. It brings together many modern and innovative business lines under the same roof with the leading organizations of the region with $500.000 \mathrm{~m} 2$ open and closed production area and approximately 1000 personnel in Ankara. Project, R\&D, Testing and Quality Control departments, CNC machining, Machining, Heat Treatment, Dyeing, and Sanding centers are the leading units. Also, after-sales services to customers in many countries around the world have $24 / 7$ service. As a firm operating in the machinery sector; the quality policy is to use advanced technology, to provide customer satisfaction by producing in time, and to comply with the relevant legislation, national and international standards.

The firm exports to many countries such as Kazakhstan, Russian Federation, Azerbaijan, Greece, Turkmenistan, Afghanistan, Syria, Saudi Arabia, Sudan, Libya, Algeria, Iraq, and Ireland. Additionally, it is among the largest working machinery manufacturing firms in Turkey. For this reason, its potential to use "Industry 4.0" applications is quite high. Within the scope of the interview, the firm's general manager, intelligent transportation systems engineer, and warehouse worker were chosen.

In general, there is no complete transition to "Industry 4.0" applications, even though the firm uses the technology extensively. However, the investments in recent technology are quite high. The fact that most of the robotic systems and software they use in production are created by their engineers. Since the firm's product range is wide, transition to "Industry 4.0" will be very costly for the firm. Nevertheless, the firm continues to invest in primary areas in Industry 4.0. According to this information, the firm has the potential to provide full integration in the future. The biggest competitors of this firm are European firms. Thus, it is crucial to increase the quality of the production to sustain a competitive edge in the world markets and it is conditional on introducing technological products. 
Ebru Aşar, Filiz Bülbül, Mansur Akbulut, Pınar Bayarslar, Tunahan Kermen, Derya Fındık

Table 1. Implementation of Industry 4.0 (AU1, AU2 and AU3)

\begin{tabular}{|c|c|c|c|c|}
\hline Categories & Concepts & AU1 (fully implemented) & AU2(almost fully implemented) & AU3 (not implemented) \\
\hline \multirow{4}{*}{ 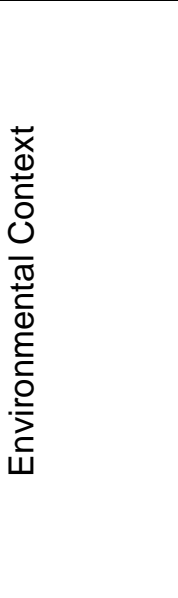 } & Customers & $\begin{array}{l}\text { Well-known global automotive } \\
\text { brand } \\
\text { All car producers operating in } \\
\text { Turkey }\end{array}$ & Well-known global automotive brand & Well-known global automotive brand \\
\hline & Competitors & $\begin{array}{l}\text { The company takes first place in } \\
\text { terms of business volume in } \\
\text { Turkey } \\
\text { All companies which produce } \\
\text { automotive spare parts around the } \\
\text { globe }\end{array}$ & $\begin{array}{l}\text { There are strong external and internal } \\
\text { competitors } \\
\text { All companies which produce } \\
\text { automotive spare parts around the } \\
\text { globe }\end{array}$ & $\begin{array}{l}\text { There are strong external and internal } \\
\text { competitors All companies which } \\
\text { produce automotive spare parts } \\
\text { around the world }\end{array}$ \\
\hline & Technologies & $\begin{array}{l}\text { Advanced hardware and software } \\
\text { Continuous investment in } \\
\text { business technologies }\end{array}$ & $\begin{array}{l}\text { Advanced hardware and software } \\
\text { Continuous investment in business } \\
\text { technologies }\end{array}$ & $\begin{array}{l}\text { Mid-level hardware and software } \\
\text { Discontinuous investment in business } \\
\text { technologies }\end{array}$ \\
\hline & & $\begin{array}{l}\text { Industry } 4.0 \text { concept can be } \\
\text { observed in business activities }\end{array}$ & $\begin{array}{l}\text { Industry } 4.0 \text { concept can be observed } \\
\text { in business activities }\end{array}$ & $\begin{array}{l}\text { Industry } 4.0 \text { concept is not } \\
\text { implemented }\end{array}$ \\
\hline \multirow{2}{*}{ 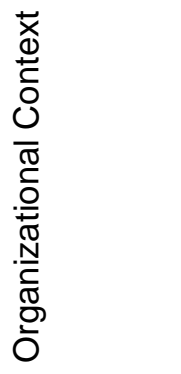 } & Corporate strategies & $\begin{array}{l}\text { To increase profitability for } \\
\text { stakeholders } \\
\text { To decrease time and costs of } \\
\text { technological development } \\
\text { To use technology to protect } \\
\text { competitive advantage }\end{array}$ & $\begin{array}{l}\text { Large market share in automotive } \\
\text { spare parts } \\
\text { To decrease time and costs of } \\
\text { technological development } \\
\text { To use technology to protect } \\
\text { competitive advantage }\end{array}$ & $\begin{array}{l}\text { Large market share in automotive } \\
\text { spare parts } \\
\text { To protect and improve the existing } \\
\text { system }\end{array}$ \\
\hline & Structure and Culture of firm & $\begin{array}{l}\text { Divided business units } \\
\text { Hierarchical structure } \\
\text { Up or out the career path }\end{array}$ & $\begin{array}{l}\text { Divided business units } \\
\text { Hierarchical structure } \\
\text { Lifetime employment (Japan culture) }\end{array}$ & $\begin{array}{l}\text { Divided business units } \\
\text { Hierarchical structure } \\
\text { Lifetime employment (Japan culture) }\end{array}$ \\
\hline \multirow{3}{*}{ 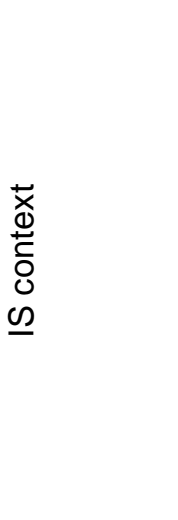 } & Role of IS for firm & $\begin{array}{l}\text { New brand systems/technologies } \\
\text { are always being developed for } \\
\text { optimal production }\end{array}$ & $\begin{array}{l}\text { New brand systems/technologies are } \\
\text { always being developed for fast- } \\
\text { growing and competitive advantage }\end{array}$ & $\begin{array}{l}\text { To ensure the continuity of the current } \\
\text { system }\end{array}$ \\
\hline & IS structure and operations & $\begin{array}{l}\text { Similar but slightly modified } \\
\text { applications for } \\
\text { departments } \\
\text { To provide integrity } \\
\text { No standardization }\end{array}$ & Integrated common applications exist & Integrated common applications exist \\
\hline & IS staff & $\begin{array}{l}\text { The innovation department } \\
\text { identifies the strategies for } \\
\text { technology } \\
\text { Skilled employees are considered } \\
\text { for recruitment }\end{array}$ & $\begin{array}{l}\text { R\&D department identifies the } \\
\text { strategies about technology } \\
\text { New graduates and skilled } \\
\text { employees are considered for } \\
\text { recruitment }\end{array}$ & $\begin{array}{l}\text { The same technology strategies for a } \\
\text { long time } \\
\text { Mid-skilled and skilled employee are } \\
\text { considered for recruitment }\end{array}$ \\
\hline
\end{tabular}

147 Özel Sayı / Special Issue I Dijital Dönüşüm ve Verimlilik / Digital Transformation and Productivity 
Table 1. (Continued)

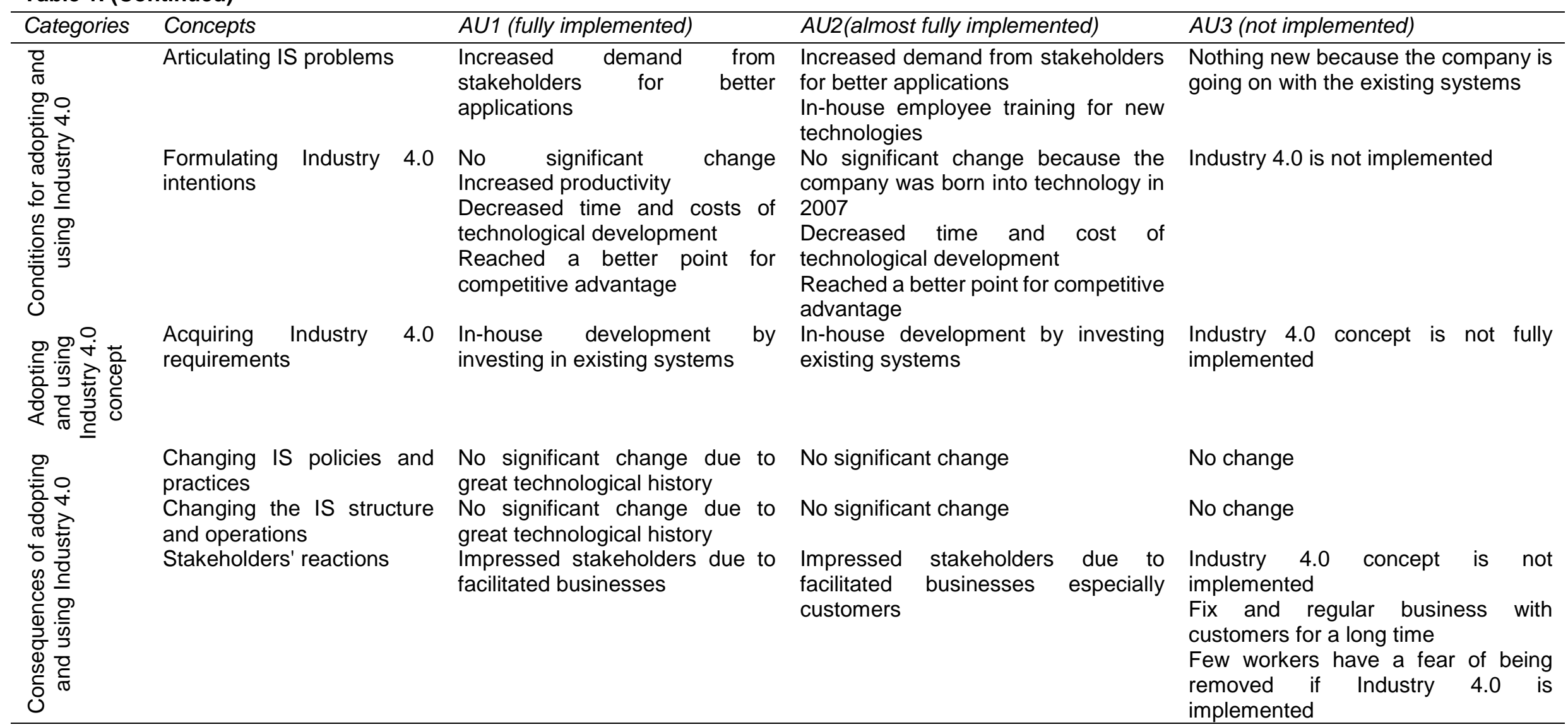


Table 2. Implementation of Industry 4.0 (AU1, MS and FS)

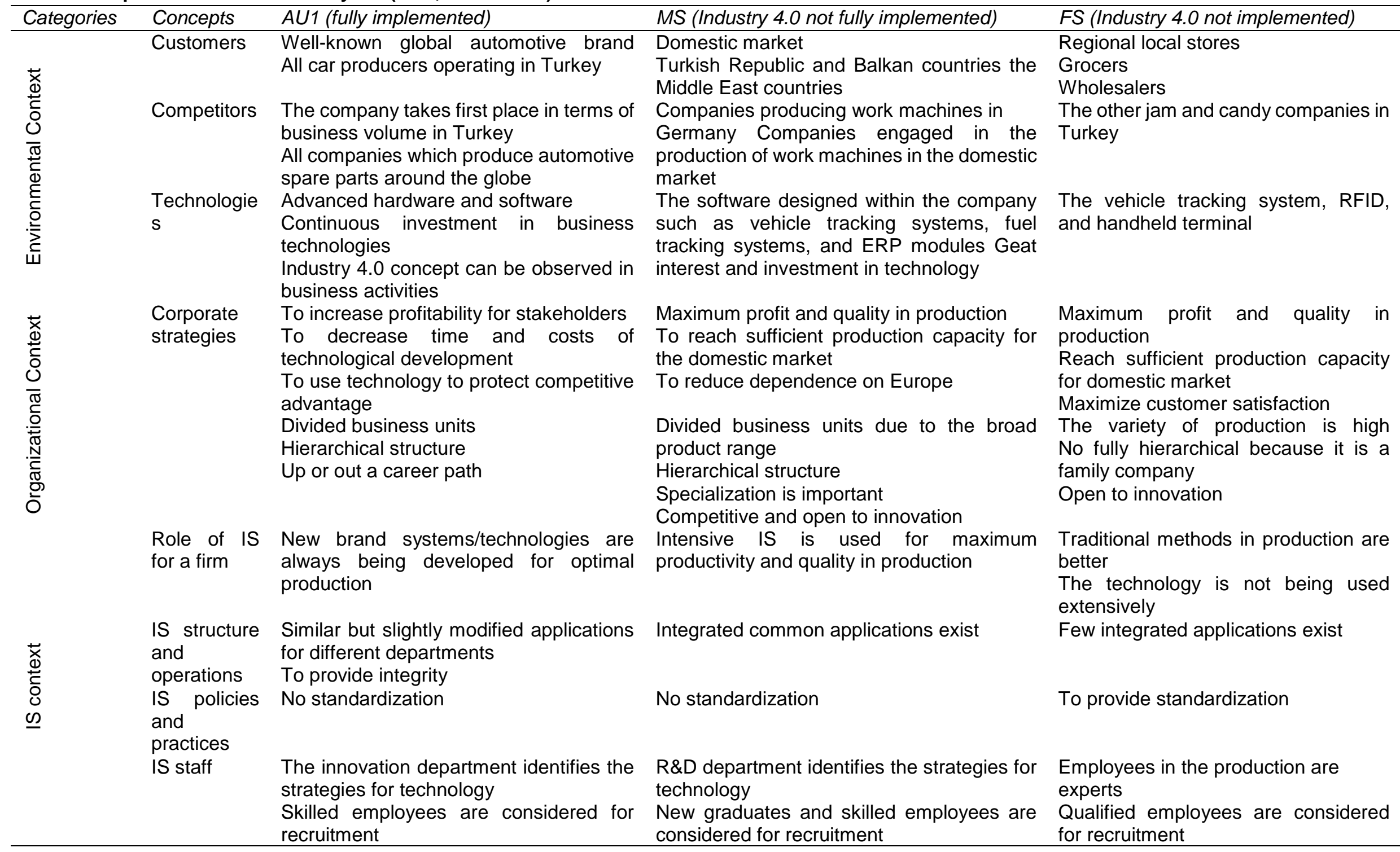


Table 2. (Continued)

\begin{tabular}{|c|c|c|c|c|}
\hline Categories & Concepts & AU1 (fully implemented) & MS (Industry 4.0 not fully implemented) & FS (Industry 4.0 not implemented) \\
\hline 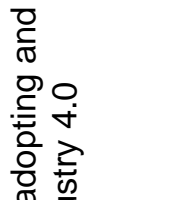 & $\begin{array}{l}\text { Articulating } \\
\text { IS problems }\end{array}$ & $\begin{array}{l}\text { Increased demand from stakeholders for } \\
\text { better applications }\end{array}$ & $\begin{array}{l}\text { The cost of new technology integration is } \\
\text { high }\end{array}$ & $\begin{array}{l}\text { The transition from the traditional } \\
\text { method to the technological method } \\
\text { (difference in the taste between } \\
\text { traditional production and } \\
\text { technological production) }\end{array}$ \\
\hline 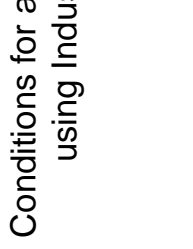 & $\begin{array}{l}\text { Formulating } \\
\text { Industry } 4.0 \\
\text { intentions }\end{array}$ & $\begin{array}{l}\text { No significant change } \\
\text { Increased productivity } \\
\text { Decreased time and costs of } \\
\text { technological development } \\
\text { Reached a better point for competitive } \\
\text { advantage }\end{array}$ & $\begin{array}{l}\text { To increase production and productivity } \\
\text { Cost reduction }\end{array}$ & $\begin{array}{l}\text { To increase production and } \\
\text { productivity } \\
\text { To reduce costs } \\
\text { To improve customer satisfaction }\end{array}$ \\
\hline 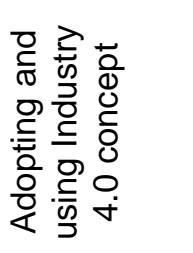 & $\begin{array}{l}\text { To acquire } \\
\text { Industry } 4.0 \\
\text { requirement } \\
\mathrm{s}\end{array}$ & $\begin{array}{l}\text { In-house development by investing in } \\
\text { existing systems }\end{array}$ & not fully implemented & $\begin{array}{l}\text { Industry } 4.0 \text { concept is not fully } \\
\text { implemented }\end{array}$ \\
\hline $\begin{array}{l}\text { O } \\
\frac{0}{\tilde{\sigma}} \\
\text { O }\end{array}$ & $\begin{array}{l}\text { Changing IS } \\
\text { policies and } \\
\text { practices }\end{array}$ & $\begin{array}{l}\text { No significant change due to great } \\
\text { technological history }\end{array}$ & No significant change & No significant change \\
\hline 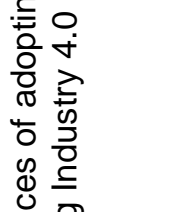 & $\begin{array}{l}\text { Changing } \\
\text { the IS } \\
\text { structure } \\
\text { and } \\
\text { operations }\end{array}$ & $\begin{array}{l}\text { No significant change due to great } \\
\text { technological history }\end{array}$ & No significant change & No significant change \\
\hline 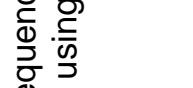 & $\begin{array}{l}\text { Stakeholder } \\
\text { s' reactions }\end{array}$ & $\begin{array}{l}\text { Impressed stakeholders due to facilitated } \\
\text { businesses }\end{array}$ & $\begin{array}{l}\text { Stakeholders are about to impress due to } \\
\text { facilitated businesses }\end{array}$ & $\begin{array}{l}\text { Industry } 4.0 \text { concept is } \\
\text { implemented }\end{array}$ \\
\hline 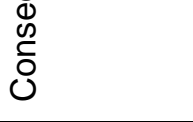 & & & $\begin{array}{l}\text { Few workers have a fear of being removed } \\
\text { from work if the industry } 4.0 \text { concept is fully } \\
\text { implemented }\end{array}$ & $\begin{array}{l}\text { Fix and regular business } \\
\text { customers for a long time }\end{array}$ \\
\hline
\end{tabular}


During the interview, participants answered all questions about Industry 4.0. Only the assembly line worker was reluctant to answer the question because he had no information about "Industry 4.0". The interview with him proceeded more on technological awareness. As far as "Industry 4.0" is considered, we concluded that future technologies create anxiety for blue-collar workers. If the firm accomplishes a complete transition to Industry 4.0, the competence and continuity of the workers will be a very important issue for them. From a managerial point of view, Industry 4.0 has no disadvantages except costs. For engineers, the intensive use of technology is a great advantage. They know that new systems can produce flawless, efficient, and quality products. For this reason, Industry 4.0 for both positions is a very important investment area.

Since the cost of infrastructure is quite high, the transition period to the "Industry 4.0 " applications does not occur rapidly. In this regard, the executive director emphasized the importance of state intervention as a solution. The excessive cost of necessary infrastructure negatively affects this process and it is thought that this problem can only be solved with government support.

As for the firm's supply chain management process, it can be observed that some Industry 4.0 technologies such as vehicle and fuel monitoring systems have been implemented. However, there is no complete transition in this section. Additionally, the supply chain process is a crucial element of the general vision of the firm. We, therefore, propose that supply chain management systems should be in the first place in the investment decision. Based on the current state of the firm and its future goals, it can be concluded that this firm can achieve full integration in the future. The transition period is not difficult for this firm, which uses technology extensively. It is thought that there will be no adaptation problem due to the presence of skilled employees in the firm.

FS

The firm operating in the food sector is one of Turkey's leading traditional food manufacturing firms. It was founded in 1989 as a family business. It produces goods such as "halva", "tahini", "molasses", "jam" and "Turkish delight". The firm emphasized the important role of the supply chain to meet customers' needs. We chose this firm to examine how the adoption process of advanced technology occurs in the low-tech sector such as food. Interviews were held with the firm's general manager and production engineer. The assembly line worker did not participate in the interview due to the intensive workload. The answers given by the manager and the engineer are similar. They do not have a deep knowledge of the issue because they use traditional methods in production.

According to the answers given by the manager and the engineer, they are aware of the concept of Industry 4.0, but no attempt has been made to apply this concept until now. There are various reasons for not adopting these technologies. First, firms rely on the existing technology since they are satisfied with the efficiency of the traditional methods. The second and most important reason is the costs of implementation. According to the engineer, the firm will keep using traditional methods in the future. However, this attitude will cause an undesired situation such as losing competitive power in the market.

Table 3 demonstrates the evaluation of firms' supply chain and Industry 4.0 situation by considering 6 variables including infrastructure, flexibility, efficiency, competitiveness, profitability, risk, and cost. The table enables us to understand why one case is different from the others.

Table 3. Evaluation of Industry 4.0 performance

\begin{tabular}{lllllll}
\hline & $\begin{array}{l}\text { Infrastructure } \\
\text { for Industry 4.0 }\end{array}$ & Flexibility & Efficiency & Competitiveness & Profitability & $\begin{array}{l}\text { Industry 4.0 } \\
\text { Implementation } \\
\text { Risk and Cost }\end{array}$ \\
\hline AU1 & Fully suitable & High level & $\begin{array}{l}\text { High } \\
\text { level }\end{array}$ & Forerunner & $\begin{array}{l}\text { Very high } \\
\text { level }\end{array}$ & Very low \\
AU2 & Suitable & High level & Midlevel & Above average & High level & Very low \\
AU3 & Suitable & Low level & Midlevel & Average & Midlevel \\
MS & Suitable & High level & Midlevel & Above average & $\begin{array}{l}\text { Very high } \\
\text { level }\end{array}$ & Low \\
FS & $\begin{array}{llllll}\text { Not fully } \\
\text { suitable }\end{array}$ & $\begin{array}{l}\text { Very low } \\
\text { level }\end{array}$ & $\begin{array}{l}\text { High } \\
\text { level }\end{array}$ & Above average & High level & Very High \\
\hline
\end{tabular}

The analysis makes it possible to compare firms from different perspectives. Scaling is performed according to the answers received in the interviews and a 1-5 rating scale is used for each variable. Infrastructure indicates the readiness of the current infrastructure of the firms regarding Industry 4.0 technologies. "Not fully suitable" means that the firm cannot shift to Industry 4.0 because its infrastructure is not ready. "Fully suitable", on the other hand, shows the presence of adequate infrastructure. We also 
include the term of flexibility which shows the exchangeability of products in the production lines and the changeability of the existing system against new advanced systems. Scaling is performed in terms of the flexibility of the production line. Efficiency reflects how well the firms use their existing systems and how efficiently these systems operate. Competitiveness gives information about the position of the firms in the Turkish market. The comparison is made based on other competitors in the same industry. Profitability shows the value of the operations while risk and cost express the consequences of adopting the Industry 4.0 concept.

AU1: Since the firm's infrastructure is fully suitable for Industry 4.0 with low implementation risk and cost, full integration is provided. Besides, the flexibility and efficiency in supply chain management (SCM) are achieved at a high level. It makes the firm have a strategic position in comparison to the others in the same industry. Considering these factors and feedbacks from the interviewees, firm AU1 has a very high margin of profitability.

AU2: Being a young firm provides a great advantage in terms of shifting to Industry 4.0. So, it has adopted this concept to a large extent and has achieved a certain level of progress such as increased flexibility and efficiency in its production lines. With the low risk and cost, the firm has above average competition rate with high profitability.

AU3: The firm's infrastructure is suitable for industry 4.0 , but due to its costs, the firm may not be able to integrate in a short time, thus flexibility is low. Although the industry has not made the transition to Industry 4.0, the market share is high which gives it a competitive advantage above the average.

MS: The firm's infrastructure is suitable for "Industry 4.0", so there is no obstacle for full integration in the future. The firm provides flexibility in SCM to a large extent. However, since full integration cannot be provided in the current situation, the level of efficiency is not that high. The use of technology is lower compared to international competitors, so the firm can compete at a moderate level. Regarding the general situation of the firm, it is one of the sector leaders with a high level of profitability. It is costly and risky to provide full integration due to the wide product range.

FS: The firm's infrastructure is not suitable for the Industry 4.0 concept and no attempt has been made to implement this concept. FS is apt to use traditional methods since they believe that they are more productive than new technologies. Additionally, they are costly and risky. Thus, flexibility in the supply chain is quite low. The productivity level, on the other hand, is high since it sustains its profitability using traditional methods, and the firm has a competitive power above the average in the market.

\section{CONCLUSION and DISCUSSION}

Industry 4.0 or Smart Manufacturing is the fourth industrial revolution. It could be a modern worldview and the joining of cutting-edge ICT and fabricating innovations. It offers successful and optimized choices. For the recognition of Smart Manufacturing, the latest modern technologies range from CPS, cloud manufacturing, enormous information analytics, loT, and smart sensors to added substance fabricating, and 3D image.

The expanded consideration developed by this new mechanical worldview commonly known as Industry 4.0 has raised numerous questions regarding the scope of the concept and its implications, as well as the innovative advancements to be fulfilled. Based on the literature review conducted at the beginning of the study, to our knowledge, no studies have examined the different sectors and the perspectives of the different layers of the firm regarding Industry 4.0 and its effect on the supply chain management system.

Prior research has documented that, Industry 4.0 implementation has positive effects on firm performance and the supply chain systems. However, these studies do not analyze the whole system in a broader perspective by considering the opinions of managers, engineers, assembly-line workers, and their future predictions. In this study, three firms from the automotive sector were evaluated and the most successful automotive firm that adopted Industry 4.0 within its Supply Chain was compared with the other two firms from the food and machinery sectors. Hence, clear considerations can be acknowledged from the usage of Industry 4.0 from these evaluations.

The collaboration between machines and people may socially affect the life of the specialists in the long run. From the analysis executed, it can be seen that the implementation of certain technologies within the supply chain process can result in both opportunities for organizational perspective and threats for employees in the long run due to the minimum involvement of human factor with the adoption of Industry 4.0. Although previous studies provide a comprehensive perspective on the implementation of Industry 4.0 (Dalenogare et al. 2018) by exploiting secondary data, this study presents detailed information about each firm by applying a case study approach. 
According to the interview results, managerial and engineer level workers of these five firms have a certain level of knowledge on Industry 4.0. Except for the firm in the food industry, which uses traditional production methods, Industry 4.0 has a positive influence on firm operations. Moreover, this study shows that Industry 4.0 integration into production systems could have negative effects on product quality which affects customer satisfaction and profitability in the long run. Workers at the bottom of the pyramidassembly line workers-also have concerns about this new concept. They worry about losing their jobs, or not being able to adapt themselves to new technology and systems. As far as the implementation of Industry 4.0 across the industry is considered, we observe that firms lag the recent developments.

There are some limitations regarding the size of the sample, which thus constrain the generalizability of this study. Further studies may include firms from different industries and other stakeholders such as competitors and suppliers. Notwithstanding limitations, this study provides a comprehensive understanding of the link between the Industry 4.0 applications and supply chain management systems. 


\section{REFERENCES}

11 $1^{\text {th }}$ Development Plan (2019-2023). https://www.sbb.gov.tr/wp content/uploads/2019/07/OnbirinciKalkinmaPlani.pdf (Erişim tarihi:30.09.2021).

Baheti, R. and Gill, H. (2011). "Cyber-Physical Systems”, The Impact of Control Technology, 12(1),161-166.

Brettel, M., Friederichsen, N., Keller, M. and Rosenberg, M. (2017). "How Virtualization, Decentralization and Network Building Change the Manufacturing Landscape: An Industry 4.0 Perspective", International Journal of Information and Communication Engineering,8(1), 37-44.

Brewster, S. (2016). "The Age of Autonomous Robots is Upon Us", https://fortune.com/2016/03/29/autonomous-robotsstartups (Erişim tarihi:10.12.2021).

Chiarini, A., Belvedere, V. and Grando, A. (2020). "Industry 4.0 Strategies and Technological Developments. Exploratory Research from Italian Manufacturing Companies", Production Planning \& Control, 31(16), 1385-1398.

Cotteleer, M. and Joyce, J. (2014). "3D Opportunity for Production: Additive Manufacturing Makes Its (Business) Case", Deloitte Review, 15, 146-161.

Dalenogare, L.S., Benitez, G.B., Ayala, N.F. and Frank, A.G. (2018). "The Expected Contribution of Industry 4.0 Technologies for Industrial Performance", International Journal of Production Economics, 204, 383-394.

Delic, M. and Eyers, D.R. (2020). "The Effect of Additive Manufacturing Adoption on Supply Chain Flexibility and Performance: An Empirical Analysis from the Automotive Industry", International Journal of Production Economics, 228,107689

Fitzgerald, J. and Quasney, E. (2017). "Using Autonomous Robots to Drive Supply Chain Innovation", Deloitte Perspectives, 1-12.

Gupta, S., Meissonier, R., Drave, V.A. and Roubaud, D. (2020). "Examining the Impact of Cloud ERP on Sustainable Performance: A Dynamic Capability View", International Journal of Information Management, 51, 102028.

Haaker, T., Ly, P.T.M., Nguyen-Thanh, N. and Nguyen, H.T.H. (2021). "Business Model Innovation Through the Application of the Internet-of-Things: A Comparative Analysis", Journal of Business Research, 126, 126-136.

He, K. and Jin, M. (2016). "Cyber-Physical Systems for Maintenance in Industry 4.0", http://www.divaportal.org/smash/get/diva2:1071443/FULLTEXT01.pdf (Erişim Tarihi: 30.09.2021).

Hermann, M., Pentek, T., Otto, B., Pentek, T. and Otto, B. (2015). "Design Principles for Industry 4.0 Scenarios: A Literature Review", 49 ${ }^{\text {th }}$ Hawaii International Conference on System Sciences (HICSS), 3928-3937.

Hofmann, E. and Rüsch, M. (2017). "Industry 4.0 and the Current Status as well as Prospects on Logistics", Computers in Industry, 89, 23-34.

Holdowsky, J., Mahto, M., Raynor, M.E. and Cotteleer, M. (2015). "Inside the Internet of Things (loT), Deloitte University Press, 1-54.

Holler, J., Tsiatsis, V., Mulligan, C., Karnouskos, S., Avesand, S. and Boyle, D. (2014). "From Machine-to-Machine to the Internet of Things: Introduction to a New Age of Intelligence", Academic Press, Oxford

Kagermann, H., Wahlster, W. and Helbig, J. (2013). "Recommendations for Implementing the Strategic Initiative Industrie 4.0", Final Report of the Industrie 4.0 Working Group, Forschungsunion: Berlin, Germany.

Mikalef, P., Krogstie, J., Pappas, I. O. and Pavlou, P. (2020). "Exploring the Relationship between Big Data Analytics Capability and Competitive Performance: The Mediating roles of Dynamic and Operational Capabilities, Information \& Management, 57(2), 103169.

Monnier, O. (2013). A Smarter Grid with the Internet of Things, Texas Instruments, 1-11.

Monostori, L. (2015). "Cyber-Physical Production Systems: Roots from Manufacturing Science and Technology", atAutomatisierungstechnik, 63(10), 766-776.

Mussomeli, A., Gish, D. and Laaper, S. (2016). The Rise of the Digital Supply Network: Industry 4.0 Enables the Digital Transformation of Supply Chains, Deloitte Insights, 1.

Orlikowski, W.J. (1993). CASE Tools as Organizational Change: Investigating Incremental and Radical Changes in Systems Development", MIS Quarterly, 309-340.

Parvin, S., Hussain, F.K., Hussain, O.K., Thein, T. and Park, J.S. (2013). "Multi-Cyber Framework for Availability Enhancement of Cyber-Physical Systems", Computing, 95(10-11), 927-948.

Prifti, V., Markja, I., Dhoska, K. and Pramono, A. (2020). "Management of Information Systems, Implementation, and Their Importance in Albanian Enterprises", IOP Conference Series: Materials Science and Engineering, 909(1), 012047. IOP Publishing.

Rüßmann, M., Lorenz, M., Gerbert, P., Waldner, M., Justus, J., Engel, P. and Harnisch, M. (2015). "Industry 4.0: The future of Productivity and Growth in Manufacturing Industries", Boston Consulting Group, 9(1), 54-89. 
Sanders, A., Elangeswaran, C. and Wulfsberg, J.P. (2016). "Industry 4.0 Implies Lean Manufacturing: Research Activities in Industry 4.0 Function as Enablers for Lean Manufacturing", Journal of Industrial Engineering and Management, 9(3), 811-833.

Schmidt, R., Möhring, M., Härting, R.C., Reichstein, C., Neumaier, P. and Jozinović, P. (2015). "Industry 4.0-Potentials for Creating Smart Products: Empirical Research Results", International Conference on Business Information Systems, 16-27.

Sniderman, B., Mahto, M. and Cotteleer, M. (2016). “Industry 4.0 and Manufacturing Ecosystems”. Deloitte University Press.

Stock, T. and Seliger, G. (2016). "Opportunities of Sustainable Manufacturing in Industry 4.0", Procedia CIRP, 40, 536541.

Tepeš, M., Krajnik, P., Kopač, J. and Semolič, B. (2015). "Smart Tool, Machine, and Special Equipment: An Overview of the Concept and Application for the Toolmaking Factory of the Future", Journal of the Brazilian Society of Mechanical Sciences and Engineering, 37(4), 1039-1053.

Thames, L. and Schaefer, D. (2016). "Software-Defined Cloud Manufacturing for Industry 4.0”, Procedia CIRP, 52, 12 17.

Tjahjono, B., Esplugues, C., Ares, E. and Pelaez, G. (2017). "What Does Industry 4.0 Mean to the Supply Chain?", Procedia Manufacturing, 13, 1175-1182.

Tortorella, G.L. and Fettermann, D. (2018). "Implementation of Industry 4.0 and Lean Production in Brazilian Manufacturing Companies”, International Journal of Production Research, 56(8), 2975-2987.

Wahlster, W., Grallert, H.J., Wess, S., Friedrich, H. and Widenka, T. (2014). "Towards the Internet of Services: The Theseus Research Program", Springer.

Zheng, T., Ardolino, M., Bacchetti, A., Perona, M. and Zanardini, M. (2019). "The Impacts of Industry 4.0: A Descriptive Survey in the Italian Manufacturing Sector", Journal of Manufacturing Technology Management, 31(5), 1085-1115. 